\title{
Preparation of compost using layer droppings with different materials
}

\author{
H Khatun*, F Alam, MA Hashem, SME Rahman
}

Department of Animal Science, Bangladesh Agricultural University, Mymensingh 2202, Bangladesh

\begin{abstract}
The experiment was carried out by anaerobic composting with layer droppings $\left(\mathrm{T}_{1}\right)$, layer droppings with straw $\left(T_{2}\right)$, layer droppings with fodder residues $\left(T_{3}\right)$ and layer droppings with saw dust $\left(T_{4}\right)$ under soil surface to study the suitable method with layer droppings and their nutrient composition. The sample from composted materials was collected at 0, 10, 20 and $30 \mathrm{~d}$ for proximate analysis. In $30 \mathrm{~d}$ of composting dry matter and organic matter were gradually decreased in every method and which were also differed among the treatments $(p<0.01)$. Crude protein $(C P)$ gradually increased in every method and was higher in $\mathrm{T}_{3}(19.43 \%)$ and then $\mathrm{T}_{1}(18.93 \%), \mathrm{T}_{4}(15.99 \%)$ and $\mathrm{T}_{2}(14.61 \%)(\mathrm{p}<0.01)$ at $20 \mathrm{~d}$ of composting. The crude fiber content gradually decreased in every method and was higher in $T_{2}$ followed by $T_{4}, T_{1}$ and $T_{3}(p<0.01)$ considerably with the composting period. Ash content was increased in all treatments with the advancing of composting period $(p<0.01)$. The $C / N$ ratio was higher in $T_{4}$ (22.4) followed by $T_{2}(22.2), T_{1}(22.0)$ and $T_{3}(21.9)(p<0.01)$ considerably with the composting period. The $\mathrm{P}^{\mathrm{H}}$ value in all treatments decreased up to first ten days then gradually increased with the increase of composting period. The $\mathrm{p}^{\mathrm{H}}$ value was higher in $\mathrm{T}_{1}$ (8.54) followed by $\mathrm{T}_{2}(8.15), \mathrm{T}_{3}(8.10)$ and $\mathrm{T}_{4}$ (8.00) $(p<0.01)$ at $30 \mathrm{~d}$ of composting period. The proximate compositions of all treatments were in acceptable range up to the end of composting period. Therefore, the results suggest that composting layer droppings with fodder residues improve the nutritional value of compost at $20 \mathrm{~d}$ of composting time.
\end{abstract}

Key words: Layer droppings, bulking agents, composting, nutritive value.

Bangladesh Animal Husbandry Association. All rights reserved. Bang. J. Anim. Sci. 2012. 41 (2): 120-123

\section{Introduction}

The poultry industry is one of the largest and fastest growing agro-based industries in Bangladesh. There is an increasing demand for poultry meat mainly due to its acceptance by most societies and its relatively low cholesterol content. The poultry industry is currently facing a number of environmental problems. One of the major problems is the accumulation of large amount of wastes, especially manure and litter, generated by intensive production, which may pose disposal and pollution problems unless environmentally and economically sustainable management technologies are evolved (Kelleher et al. 2002; Sharpley et al. 2007).

Composting is a simple and natural option that can be used to produce a marketable product. It is a more stable and more consistent material that fresh droppings. It contains all essential nutrients including micronutrients and it has been well documented that it provides a valuable source of plant nutrients (Williams et al. 1999; Harmel et al. 2009). Addition of poultry manure to soils not only helps to overcome the disposal problems but also enhances the physical, chemical and biological fertility of soils (Friend et al. 2006; McGrath et al. 2009). Compost pile needs a proper ratio of carbon-rich materials, and/or nitrogen-rich materials. Carbon-rich materials are dried leaves, straw, and wood chips. Nitrogen materials are fresh or green, such as grass clippings and kitchen scraps. Mixing certain types of bulking materials with layer droppings changing the rate of decomposition and quality of compost (Cobb and Rosenfield 1991). Therefore, the present study was undertaken to determine the effectiveness of different bulking materials in reducing time of composting and to assess its quality on the composting process.

\section{Materials and Methods}

The experiment was carried out in the Goat and Sheep farm, Department of Animal Science, Bangladesh Agricultural University, Mymensingh, during the period from February to March 2012. The experiment was laid out in a Complete Randomized Design (CRD) with 3 replicate in each treatment. A place of comparatively high land was selected to prepare 12 similar pits whose diameter were $75 \mathrm{~cm}$ and depth $45 \mathrm{~cm}$. Polyethylene bags 
were set at the bottom and side wall of the pits to prevent leaching and water contamination from compost. After collection, all bulking materials except the sawdust, were cut by chopping machine to mix with layer droppings properly. The treatment of the experiment was mentioned as: layer droppings only $\left(T_{1}\right)$, layer droppings with straw $\left(T_{2}\right)$, layer droppings with fodder residues $\left(T_{3}\right)$ and layer droppings with sawdust $\left(T_{4}\right)$.

In each treatment, $20 \mathrm{~kg}$ layer droppings were mixed with the bulking materials to fix the moisture level at $50 \%$. After proper mixing of the materials, sample was collected from each treatment for chemical analysis. Then mixing materials were mixed in previously prepared pits according to the treatment, covered with eight $\mathrm{cm}$ soil layer and kept for $30 \mathrm{~d}$ for successful composting.

For chemical analysis samples were taken at $10 \mathrm{~d}$ interval from all composting pits and $\mathrm{pH}$ of compost was determined by using a laboratory $\mathrm{p}^{\mathrm{H}}-\mathrm{mV}$ meter (ino Lab, Germany) after putting $2 \mathrm{~g}$ sample in $50 \mathrm{ml}$ distill water. Dry matter was determined by drying the compost at $65^{\circ} \mathrm{C}$ for 48 h. Crude Protein (CP) was measured using Kjeldahl method $(\mathrm{N} \times 6.25)$ while other proximate constituents, ether extract (EE), ash, crude fiber (CF) and nitrogen free extract (NFE) were determined according to procedures described by AOAC (2004). For determination of carbonnitrogen $(\mathrm{C} / \mathrm{N})$ ratio, Carbon is calculated from organic matter divided by 1.73 factors and nitrogen from crude protein divided by 5.88 constant factors. The $\mathrm{C} / \mathrm{N}$ ratio is a parameter used to determine the compost is nitrogen stable. Composts that are derived primarily from wood by-products have high carbon to nitrogen ratios unless additional nitrogen is added during the composting process.
The data were analyzed using the "SAS" statistical program to compute analysis of variance (ANOVA) for a Completely Randomized Design (CRD) and significant mean values were tested with Duncan's Multiple Range Test (Gomez and Gomez, 1984).

\section{Results}

\section{Chemical composition of compost}

The nutritive value of the compost was significantly influenced by the bulking materials in all treatments (Table 1 ). At $0 \mathrm{~d}$ of composting, DM content did not significantly $(p<0.05)$ variy in all treatments. The highest crude protein (CP) content was observed in compost with Layer droppings $\left(T_{1}\right)$ and layer droppings with fodder residues $\left(T_{3}\right)$ which was significantly $(p<0.01)$ varied from other treatments. The highest crude fibre (CF) was observed in compost with Layer droppings and straw, which was significantly $(p<0.01)$ varied from other treatments. Ash contents differ significantly $(p<0.01)$ in different treatments.

At $10 \mathrm{~d}$ of layer droppings composting, DM content differed significantly $(p<0.01)$ among different treatments and highest DM content was observed in compost with layer droppings and fodder residues $\left(\mathrm{T}_{3}\right)$ whereas lowest in only layer droppings $\left(T_{1}\right)$ compost. Crude protein (CP) content was not significantly $(p<0.05)$ varied in different treatments. Crude fibre (CF) contents was similar in layer droppings $\left(T_{1}\right)$ compost and compost with layer droppings and fodder residues $\left(T_{3}\right)$. The highest CF was observed in compost with layer droppings and straw. Ash content was significantly $(p<0.05)$ varied in all treatments. The highest Ash content $(21.1 \%)$ was observed in compost with layer droppings and sawdust.

Table 1. Effect of different bulking materials on chemical composition (\%) of compost at different days

\begin{tabular}{|c|c|c|c|c|c|c|c|c|c|c|c|c|c|c|c|c|}
\hline \multirow{2}{*}{ Treat. } & \multicolumn{4}{|c|}{ Dry matter } & \multicolumn{4}{|c|}{ Crude protein } & \multicolumn{4}{|c|}{ Crude fibre } & \multicolumn{4}{|c|}{ Ash } \\
\hline & $0-d$ & $10-d$ & $20-d$ & $30-d$ & $0-d$ & $10-d$ & $20-d$ & $30-d$ & $0-d$ & 10-d & $20-d$ & $30-d$ & $0-d$ & $10-d$ & $20-d$ & $30-d$ \\
\hline $\mathrm{T}_{1}$ & $\begin{array}{l}47.9 \\
\pm 0.2\end{array}$ & $\begin{array}{l}47.9^{c} \\
\pm 0.2\end{array}$ & $\begin{array}{c}48.1^{c} \pm \\
0.4\end{array}$ & $\begin{array}{l}47.3^{c} \\
\pm 0.3\end{array}$ & $18.9^{\mathrm{a}} \pm 0.1$ & $\begin{array}{l}18.4 \\
\pm 0.4\end{array}$ & $18.9^{b} \pm 0.2$ & $\begin{array}{l}17.2^{\mathrm{a}} \\
\pm 0.1\end{array}$ & $\begin{array}{l}18.1^{\mathrm{c}} \\
\pm 0.1\end{array}$ & $\begin{array}{l}15.6^{c} \\
\pm 0.1\end{array}$ & $\begin{array}{l}14.1^{d} \\
\pm 0.1\end{array}$ & $\begin{array}{l}12.2^{\mathrm{c}} \\
\pm 0.1\end{array}$ & $\begin{array}{l}12.8^{d} \\
\pm 0.1\end{array}$ & $\begin{array}{l}14.9^{c} \\
\pm 0.2\end{array}$ & $\begin{array}{l}11.3^{d} \\
\pm 0.2\end{array}$ & $\begin{array}{l}12.9^{c} \\
\pm 0.4\end{array}$ \\
\hline $\mathrm{T}_{2}$ & $\begin{array}{l}47.9 \\
\pm 0.1\end{array}$ & $\begin{array}{l}49.1^{c} \\
\pm 0.2\end{array}$ & $\begin{array}{l}49.1^{b} \\
\pm 0.4\end{array}$ & $\begin{array}{l}52.3^{\mathrm{a}} \\
\pm 0.4\end{array}$ & $\begin{array}{l}17.5^{c} \\
\pm 0.1\end{array}$ & $\begin{array}{c}17.3 \\
\pm 0.4\end{array}$ & $\begin{array}{l}14.6^{d} \\
\pm 0.1\end{array}$ & $\begin{array}{l}15.9^{c} \\
\pm 0.1\end{array}$ & $\begin{array}{l}22.4^{\mathrm{a}} \\
\pm 0.3\end{array}$ & $\begin{array}{c}19.6^{\mathrm{a}} \\
\pm \\
0.3\end{array}$ & $\begin{array}{c}19.3^{\mathrm{a}} \\
\pm .1\end{array}$ & $\begin{array}{l}15.1^{\mathrm{a}} \\
\pm 0.1\end{array}$ & $\begin{array}{c}16.6^{\mathrm{a}} \pm \\
0.1\end{array}$ & $\begin{array}{l}17.0^{\mathrm{b}} \\
\pm 0.1\end{array}$ & $\begin{array}{c}17.2^{\mathrm{a}} \pm \\
0.2\end{array}$ & $\begin{array}{l}21.1^{\mathrm{a}} \\
\pm 0.1\end{array}$ \\
\hline $\mathrm{T}_{3}$ & $\begin{array}{l}47.4 \\
\pm 0.3\end{array}$ & $\begin{array}{l}52.3^{a} \\
\pm 0.3\end{array}$ & $\begin{array}{l}53.2^{a} \\
\pm 0.3\end{array}$ & $\begin{array}{l}48.1^{b} \\
\pm 0.3\end{array}$ & $\begin{array}{l}18.0^{\mathrm{b}} \\
\pm 0.2\end{array}$ & $\begin{array}{l}18.1 \\
\pm 0.3\end{array}$ & $\begin{array}{l}19.4^{\mathrm{a}} \\
\pm 0.1\end{array}$ & $\begin{array}{c}17.1^{\mathrm{ab}} \\
\pm 0.3\end{array}$ & $\begin{array}{l}20.3^{b c} \\
\pm 0.2\end{array}$ & $\begin{array}{c}15.2^{\mathrm{c}} \\
\pm \\
0.1\end{array}$ & $\begin{array}{l}15.1^{b} \\
\pm 0.1\end{array}$ & $\begin{array}{l}12.1^{\mathrm{c}} \\
\pm 0.2\end{array}$ & $\begin{array}{l}13.5^{c} \\
\pm 0.2\end{array}$ & $\begin{array}{l}15.1^{c} \\
\pm 0.1\end{array}$ & $\begin{array}{l}15.9^{\mathrm{b}} \\
\pm 0.1\end{array}$ & $\begin{array}{l}11.1^{c} \\
\pm 0.1\end{array}$ \\
\hline $\mathrm{T}_{4}$ & $\begin{array}{l}47.6 \\
\pm 0.3\end{array}$ & $\begin{array}{l}50.1^{b} \\
\pm 0.3\end{array}$ & $\begin{array}{l}48.6^{c} \\
\pm 0.4\end{array}$ & $\begin{array}{l}45.2^{d} \\
\pm 0.3\end{array}$ & $\begin{array}{l}15.3^{d} \\
\pm 0.2\end{array}$ & $\begin{array}{c}17.4 \\
\pm 0.4\end{array}$ & $\begin{array}{l}15.9^{c} \\
\pm 0.3\end{array}$ & $\begin{array}{l}14.5^{d} \\
\pm 0.2\end{array}$ & $\begin{array}{l}21.2^{\mathrm{b}} \\
\pm 0.2\end{array}$ & $\begin{array}{c}18.1^{b} \\
\pm \\
0.1\end{array}$ & $\begin{array}{l}15.1^{\mathrm{b}} \\
\pm 0.1\end{array}$ & $\begin{array}{l}13.9^{b} \\
\pm 0.1\end{array}$ & $\begin{array}{c}14.9^{b} \pm \\
0.1\end{array}$ & $\begin{array}{l}21.8^{a} \\
\pm 0.4\end{array}$ & $\begin{array}{c}14.3^{\mathrm{C}} \pm \\
0.1\end{array}$ & $\begin{array}{l}17.9^{\mathrm{b}} \\
\pm 0.1\end{array}$ \\
\hline LS & NS & $* *$ & $* *$ & $* *$ & $* *$ & NS & $* *$ & $* *$ & $* *$ & $* *$ & $* *$ & $* *$ & $* *$ & $* *$ & $* *$ & $* *$ \\
\hline
\end{tabular}


NS, non significant, $* *, p<0.01$, means in same column with different superscript differ significantly; $\mathrm{T}_{1}$, only layer droppings, $T_{2}$, layer droppings with straw, $T_{3}$, layer droppings with fodder residues, $T_{4}$, layer droppings with sawdust

At $20 \mathrm{~d}$ of layer litter composting, the highest DM content was observed in compost with layer droppings and fodder residues which was statistically identical to compost with only layer droppings. Crude protein (CP) content was also highest in compost with layer droppings and fodder residues. Crude fibre (CF) content was highest $(19.26 \%)$ in compost with layer droppings and straw and the lowest in compost with only layer droppings. The highest ash was observed in compost with layer droppings and straw.

At $30 \mathrm{~d}$ of composting, the highest DM content $(52.28 \%)$ was observed in compost made from layer droppings and straw, followed by compost with layer droppings and fodder residues, compost with layer droppings with sawdust and compost with only layer droppings. The highest $\mathrm{CP}$ content was observed in compost with only layer droppings which was statistically identical to compost with layer droppings and fodder residues. Crude fibre (CF) content was similar in compost with only layer droppings and compost with layer droppings and fodder residues. Ash contents differ significantly $(p<0.01)$ in all treatments and highest value $(21.11 \%)$ was observed in compost with layer droppings and straw.

\section{$\mathrm{C} / \mathrm{N}$ and $\mathbf{p H}$ of compost at different days}

The $\mathrm{C} / \mathrm{N}$ ratio of different compost is shown in Figure 1 . The $\mathrm{C} / \mathrm{N}$ ratios were decreased in all treatments with the advancing of composting period $(p<0.01)$. It was differ significantly $(p<0.01)$ in all treatments and higher value was obtained in $\mathrm{T}_{4}$ (22.4) followed by $\mathrm{T}_{2}$ (22.2), $\mathrm{T}_{1}$ (22) and $T_{3}(21.9) \quad(p<0.01)$ considerably with the composting period.

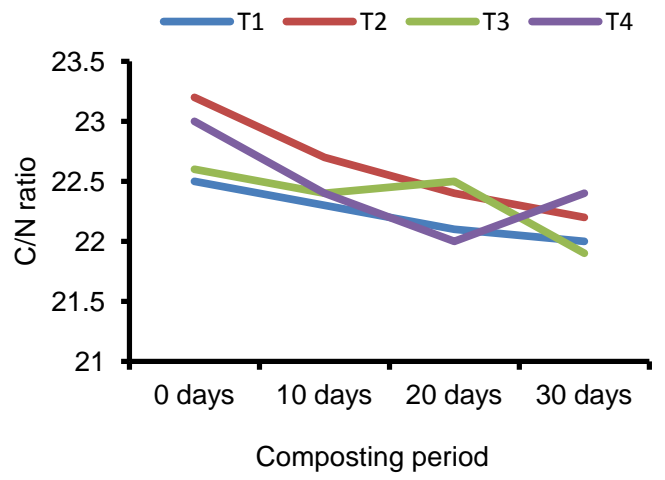

Figure 1. Effect of $\mathrm{C} / \mathrm{N}$ on layer droppings compost at different days

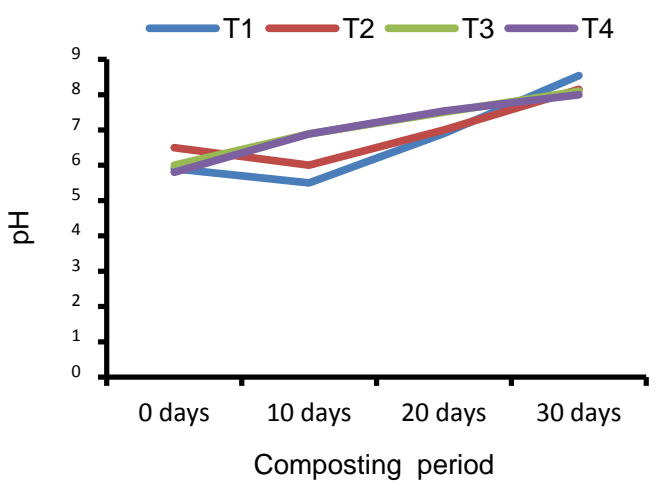

Figure 2. Effect of $\mathrm{pH}$ on layer droppings compost at different days

The values of $\mathrm{pH}$ of composting at different duration are shown in Figure 2. The $\mathrm{p}^{\mathrm{H}}$ value of composting differed significantly $(p<0.01)$ beteen treatments. The $\mathrm{p}^{\mathrm{H}}$ value decreased upto first ten days then gradually increased with the composting period. The $\mathrm{pH}$ value was higher in $\mathrm{T}_{1}$ (8.54) followed by $T_{2}(8.15), T_{3}(8.10)$ and $T_{4}$ (8.00) $(p<0.01)$ at $30 \mathrm{~d}$ of composting period. The lower $\mathrm{p}^{\mathrm{H}}$ of compost indicates good fermentation quality which was due to presence higher water soluble carbohydrates. The lower $\mathrm{p}^{\mathrm{H}}$ of compost indicates good fermentation quality.

\section{Discussion}

In the past decade, a number of commercial products and organic materials such as straw, peat, woodchip, paper waste, crop residues have been suggested to farmers for addition to manure to obtain beneficial effects of composting (Barrington et al. 2002; Heber et al. 2001). In this study compost with layer droppings and crop residues showed highest dry matter content (53.18\%) at $20 \mathrm{~d}$ of composting to compare that at $30 \mathrm{~d}$ of composting. The same result was also observed by Adeley and Kitts (1983) and Muller (1982) who reported that dry matter content decreased during composting period.

The highest CP content (19.43\%) was observed in layer droppings composting with crop residues at $20 \%$ d of composting. The results were consistent with Coddling (2006) and Taufik et al. (1997) but 
contradict with Abdelmawa et al. (1988) when composted by staking.

In the beginning of the composting process, CF content was highest in all treatments and with increasing the composting period it was gradually decreased. The ash value increased due to prolongation of composting period and result was similar with the observation of Jacob et al. (1997) who observed that composting reduced organic matter that raises the ash value.

In this experiment, the $\mathrm{C} / \mathrm{N}$ ratios decreased in all treatments with the advancing of composting period $(p<0.01)$ and at first up to ten days $\mathrm{pH}$ also decreased in all treatments and then gradually increased with prolong the composting period (Figure 1and 2). The results are similar with the observation of Jacob et al. (1997).

\section{Conclusion}

The results suggest that composting layer droppings with fodder residues significantly improves the nutritional values of compost at 20 days of composting time and may be a feasible means of preserving and converting layer droppings, into a good organic fertilizer for plant. In addition, this approach may also solve the disposal problem of poultry droppings in large poultry industries by utilizing it as fertilizer.

\section{References}

Abdelmawla SM, Fontenot JP and El-Ashry MA (1988). Composited, deepstacked and ensiled broiler litter in sheep diets: Chemical composition and nutritive value study. Anim. Sci. Res. Rep. 7: 127.

Adeleye IOA and Kitts WD (1983). Poultry wastes as feed for ruminants II. Effect of age of chemical composition of broiler litter and caged layer droppings. Tropical Anim. Prod. 8: 15-18.

AOAC. 2004. Association of the Official Agricultural Chemists, Official methods of analysis. Washiington, DC. P. 1-34.

Barrington S, Choiniere $D$, Trigui $M$ and Knight W (2002) 'Effect of carbon source on compost nitrogen and carbon losses', Bioresource Technol., Vol. 83, pp.189-194.

Cobb K and Rosenfield J (1991). Municipal Compost Management. Cornell University Waste Management Institute.

Coddling EE (2006). Laboratory characterization of extractable phosphorus in poultry litter and poultry litter ash. Soil Sci. 171: 858-864.
Friend AL, Roberts SD, Schoenholtz SH, Mobley, JA and Gerard PD (2006). Poultry litter application to Loblolly pine forests: Growth and nutrient containment. J. Environ. Qual. 35: 837-848.

Gomez KA, Gomez AA. (1984). Statistical procedure for Agricultural Research. $2^{\text {nd }}$ End. New York : John Wiley and Sons. P. 680.

Harmel RD, Smith DR., Haney R.L and Dozier M (2009). Nitrogen and phosphorus runoff from cropland and pasture fields fertilized with poultry litter. Journal of soil and water conservation 64: 400-412.

Heber $\mathrm{AJ}, \mathrm{Ni}$ J, Sutton AL, Patterson JA, Fakhoury KJ, Kelly DT and Shao P (2001). Laboratory Testing of Commercial Manure Additives for Swine Odor Control, Agricultural Air Quality Laboratory, Purdue University, West Lafayette, IN.

Jacob JP, Kunkle RS, Trevola RS, Miles RD and Mather FB (1997). Broiler Litter, Part 1: A feed ingredient for ruminants. University of Florida. Cooperative Extension Service. Institute of Food and Agricultural Science.

Kelleher BP, LeahY JJ, Henihan AM, O'dwyer TF, Sutton D and Leahy MJ (2002). Advances in poultry litter disposal technology- a review. Bioresource Technology 83: 27-36.

McGrath S, Maguire RO, Tacy BF and Kike JH (2009). Improving soil nutrition with poultry litter application in low input forage systems. Agronomy J. 102: 48-54.

Muller ZO (1982). Feed from animal wastes. Feeding manual. FAO Animal Production and Health. Paper No. 28, Rome, cited from Asian. Aus. J. Anim. Sci. 5: 595.

Sharpley AN, Herron S and Daniel T (2007). Overcoming the challenges of phosphorusbased management challenges in poultry farming. J. Soil and Water Conser. 58: 3038.

Taufik DE, Said G and Maarif MS (1997). Study of Preparation of Organic Fertilizer through the Composting of Domestic Wastes Using Liquid Mud of Oxidation Pond. Technology Industry Pertanian. In: Organic Recycling in Asia and the Pacific, RAP Bull. Reg. Office for the Asia and the Pacific, Food and Agril. Org., Bangkok, Thailand. 13: 67.

Williams CM, Barker JC and Sims JT (1999). Management and utilization of poultry wastes. Rev. Environ. Contamination and Toxicology. 162: 105-157. 
Nutrient composition of compost of layer droppings 